\title{
Treatment failures with multidrug therapy
}

\section{LOBO}

\section{Introduction}

Multidrug treatment (MDT) for leprosy has been in extensive use in India since 1982-83. A study of patients who received MDT in programmes run by 15 non-governmental voluntary organizations (NGOs) in India since 1983, is presented here. These NGOs are located in different geographical regions in the following States of India-Andhra Pradesh, Karnataka, Kerala, Maharashtra and Tamilnadu.

The main aim of the study was to measure the overall success of MDT using the following simple parameters:

a Number and proportion of patients declared as cured and released from treatment or released from control.

b Number and proportion of treatment 'drop-outs'.

c Number and proportion of treatment failures including relapses.

\section{Patients and methods}

A total of 67,472 patients from 15 NGOs who received MDT from 1983 to date, are included in the study.

The patients received the treatment regimens described below.

PAUCIBACILLARY (PB)

This includes patients that have polar tuberculoid (TT), indeterminate (I), primary neuritic (PN) and borderline-tuberculoid (BT) with less than 10 skin/nerve lesions and who are skin-smear negative.

Rifampicin (RMP), $600 \mathrm{mg}$ once/month supervised;

Dapsone (DDS), $100 \mathrm{mg}$ daily unsupervised;

Duration, 6-12 months.

MULTIBACILLARY (MB)

This includes patients that have mid-borderline $(\mathrm{BB})$, borderline lepromatous $(\mathrm{BL})$, polar 
lepromatous (LL) and borderline-tuberculoid (BT) and who are skin-smear positive and/ with more than $10 \mathrm{skin} /$ nerve lesions. Either:

1 Standard WHO regimen (all $\mathrm{mg}$ ):

Supervised once in 28 days
RMP 600
CLOF 300
DDS 100

Unsupervised daily for 27 days

CLOF 50

DDS 100

or

2 Modified WHO regimen as recommended by the National Leprosy Eradication Programme (NLEP):

Supervised daily for 14 days

$\begin{array}{ll}\text { RMP } & 600 \\ \text { CLOF } & 100 \\ \text { DDS } & 100\end{array}$

Followed by the Standard WHO regimen as in 1 above.

Duration: minimum 2 years or until bacteriologically negative.

\section{TREATMENT FAILURES}

The treatment failures have been classified into 4 groups:

1 PB cases who showed active signs at the end of 12 doses and were given MB treatment with 3 drugs for a minimum of 2 years thereafter.

$2 \mathrm{MB}$ cases who showed clinically active signs with or without bacteriological reduction at the end of 36 doses of MB treatment with 3 drugs.

$3 \mathrm{~PB}$ or $\mathrm{MB}$ cases who have been classified as relapse and re-started treatment during or after surveillance.

$4 \mathrm{~PB}$ or MB cases who manifested severe Type I or Type II reactions, which necessitated temporary or permanent stoppage of MDT.

\section{CRITERIA FOR SIGNS OF ACTIVITY}

The criteria for signs of activity have not been uniform. However, the following signs in general have been considered as active:

1 Increase in the size of the lesion or anaesthetic area;

2 appearance of new lesions;

3 erythema;

4 tenderness of nerves;

5 Type II reactions;

6 increase in the bacteriological index (BI). 
RELAPSE

Relapse has been defined as the re-appearance of the signs of activity and/or appearance of new lesions and/or bacteriological positivity during or after surveillance.

\section{Results}

Table 1. Cases under study and proportion of drop-outs

\begin{tabular}{lrrrr}
\hline & & & & Proportion \\
Patient details & PB & MB & Total & $(\%)$ \\
\hline 1 Total number of patients who received MDT & 52,398 & 15,074 & 67,472 & \\
2 Patients eliminated as drop-outs (incomplete treatment) & 2,523 & 1,709 & 4,232 & $06 \cdot 28$ \\
3 Patients remaining for the study & 49,875 & 13,365 & 63,240 & $93 \cdot 72$ \\
\hline
\end{tabular}

Table 2. Analysis of study cases

\begin{tabular}{lrrrr}
\hline & & & & Proportion \\
Patient details & PB & MB & Total & $(\%)$ \\
\hline 1 Patients available for study & 49,875 & 13,365 & 63,240 & \\
2 Patients declared RFT/RFC & 41,729 & 9,488 & 51,217 & $81 \cdot 0$ \\
3 Patients presently under treatment & 8,146 & 3,877 & 12,023 & $19 \cdot 0$ \\
\hline
\end{tabular}

Table 3(a). Analysis of treatment failures excluding relapses

\begin{tabular}{lrrrrr}
\hline & & & & & Proportion \\
Patient details & PB & MB & Total & \begin{tabular}{c} 
(\%) \\
\hline 1 Patients availabe for study
\end{tabular} \\
\hline Patients recorded as treatment failures & 49,875 & 13,365 & 63,240 & \\
& 1,424 & 269 & 1,693 & $2 \cdot 7$ \\
\hline
\end{tabular}

Table 3(b). Profile of different groups of treatment failures excluding relapses

\begin{tabular}{|c|c|c|c|c|c|}
\hline \multirow[b]{2}{*}{ Patient details } & \multirow[b]{2}{*}{ PB } & \multirow[b]{2}{*}{ MB } & \multirow[b]{2}{*}{ Total } & \multicolumn{2}{|c|}{ Proportion to } \\
\hline & & & & $\begin{array}{l}\text { Failures } \\
(\%)\end{array}$ & $\begin{array}{c}\text { Study cases } \\
(\%)\end{array}$ \\
\hline $\begin{array}{l}1 \text { PB cases-active after } 12 \text { doses-received MB } \\
\text { (regimen thereafter) }\end{array}$ & & & 1,426 & $84 \cdot 2$ & $2 \cdot 25$ \\
\hline $\begin{array}{l}2 \text { MB cases who showed clinically active signs } \\
\text { (after } 36 \text { doses) }\end{array}$ & & & 197 & $11 \cdot 6$ & $0 \cdot 31$ \\
\hline $\begin{array}{l}3 \mathrm{~PB} / \mathrm{MB} \text { cases who manifested Type I/Type II } \\
\text { reactions prompting stoppage of MDT }\end{array}$ & 57 & 13 & 70 & $4 \cdot 2$ & $0 \cdot 11$ \\
\hline 4 Total number considered as failures & & & 1,693 & & $2 \cdot 67$ \\
\hline
\end{tabular}


Table 4. Proportion of relapses

\begin{tabular}{|c|c|c|c|c|}
\hline Patient details & PB & MB & Total & $\begin{array}{c}\text { Proportion } \\
(\%)\end{array}$ \\
\hline 1 Total number of patients declared RFT/RFC & 41,729 & 9,488 & 51,217 & \\
\hline 2 Patients recorded as relapsed & $123(0 \cdot 29 \%)$ & $31(0 \cdot 32 \%)$ & 154 & $0 \cdot 3$ \\
\hline
\end{tabular}

Table 5. Profile of MB relapses (Available for 17 out of 31 recorded cases)

\begin{tabular}{|c|c|c|}
\hline Duration (months) & \multirow{2}{*}{$\begin{array}{l}\text { No. of } \\
\text { cases }\end{array}$} & \multirow[b]{2}{*}{ Percentage } \\
\hline Relapse & & \\
\hline $6-12$ & 4 & $23 \cdot 6$ \\
\hline $12-18$ & 3 & $17 \cdot 6$ \\
\hline $18-24$ & 2 & $11 \cdot 8$ \\
\hline More than 24 & 8 & $47 \cdot 0$ \\
\hline \multicolumn{3}{|l|}{ Criteria for diagnosis } \\
\hline Clinical only & 8 & $47 \cdot 0$ \\
\hline Bacteria only & 1 & $6 \cdot 0$ \\
\hline Clinical \& bacteria & 8 & $47 \cdot 0$ \\
\hline
\end{tabular}

Note-the balance of 14 relapses are from one centre, the Sacred Heart Leprosy Centre, in Tamilnadu.

Table 6. Profile of PB relapses (Available for 108 out of 123 recorded cases)

\begin{tabular}{|c|c|c|}
\hline Duration (months) & \multirow{2}{*}{$\begin{array}{l}\text { No. of } \\
\text { cases }\end{array}$} & \multirow[b]{2}{*}{ Percentage } \\
\hline Relapse & & \\
\hline $6-12$ & 27 & $25 \cdot 0$ \\
\hline $12-18$ & 31 & $28 \cdot 7$ \\
\hline $18-24$ & 20 & $18 \cdot 5$ \\
\hline More than 24 & 30 & $27 \cdot 8$ \\
\hline \multicolumn{3}{|l|}{ Criteria for diagnosis } \\
\hline Clinical only & 107 & $99 \cdot 1$ \\
\hline Bacterial only & - & - \\
\hline Clinical \& bacterial & 1 & $0 \cdot 9$ \\
\hline
\end{tabular}

Note-the balance of 15 relapses are from one centre, the Sacred Heart Leprosy Centre, in Tamilnadu.

\section{Discussion}

The study proves that most patients who receive MDT satisfactorily complete the 
treatment and are declared as cured and released from treatment within 6-12 months in PB leprosy or 24-36 months in MB leprosy.

A deliberate attempt was made to give a much wider definition of treatment failures that included apart from relapses, patients who did not become inactive within the stipulated duration of 12 months in PB and 36 months in MB cases and $77 \cdot 2 \%$ of cases recorded as treatment failures belong to this category. Most of them are not really failures but required additional treatment with 3 drugs instead of 2 drugs in PB cases or additional duration of treatment (beyond 36 months) in MB cases. About $6 \cdot 3 \%$ of the cases are recorded as drop-outs. The percentage of relapses is only $0 \cdot 3 \%$ and those where a stoppage of treatment was prompted is $0 \cdot 1 \%$.

It needs to be emphasized that the diagnosis of relapse has been made on clinical and/ or bacteriological (skin-smear) grounds only. No case was subjected to mouse-footpad inoculation. About $25 \%$ of the MB as well as PB relapses (Tables 5 and 6) were diagnosed between 6 and 12 months after release from treatment (RFT) and another $17 \cdot 6 \%$ of MB relapses and $28.7 \%$ of PB relapses were diagnosed between 12 and 18 months after RFT. It is likely that most of these cases recorded as relapses were late reversal reactions. This is further corroborated by the fact that $47 \%$ of the MB relapses were made on clinical grounds alone. Out of 55,449 cases due for release from treatment, $51,217(92 \cdot 2 \%)$ were duly declared as RFT.

\section{Conclusions}

A study of 67,472 patients from 15 NGOs working in India who received MDT has been presented. The large majority of patients $(92 \cdot 2 \%)$ completed satisfactory treatment, were declared as cured and released from treatment, within the stipulated duration, thus proving that the MDT standard of WHO or the modified WHO/NLEP(India) regimen is:

effective;

- acceptable to patients; and

-easy to implement in India.

About $2.56 \%$ of the patients required treatment for longer or required additional treatment with 3 drugs instead of 2 .

The percentage of relapses was $0 \cdot 3 \%$. MDT can thus be expected to produce a steady decline in the quantum of leprosy infection in the community and a steady decline in prevalence/incidence rates. The goal of eradication is achievable if MDT is properly implemented.

\section{Acknowledgments}

My thanks are due to my colleagues Dr M Mathews, Dr S Thirunavukarasu, Mr R Narayanan, Mr R Ramanujam and Mr Nabi Thiagarajan for helping me in compiling results from various institutions.

I am also grateful to the Directors/Medical Officers of the following NGOs who kindly provided details of patients who received MDT in their centres: 
1 Emmaus-Swiss Palamaner Project, Palamaner 517 408, Andhra Pradesh-Dr A Jacob and Dr Rajendran.

2 Shivananda Rehabilitation Home, Kukatpally, Hyderabad 500 872-Dr Hrishikesh and Dr Anand Reddy.

3 GREVALTES, Visakapatnam 530 001, Andhra Pradesh-Dr K S Sudhakar.

4 Leprosy Control Project, CSI Hospital, Bangalore 560 051, Karnataka State-Dr (Mrs) Chandra Thomas.

5 Hind Kusht Nivaran Sangh, Mangalore 575 001, Karnataka State-Dr J N Shetty and Dr M Subhash.

6 CULTES, Perumpadappu, Cochin 682 006-Dr A G Thomas and Mr C P Mathew.

7 Maharashtra Lokahita Seva Mandal, Bombay 400 054, Maharashtra State-Dr R D Kharkhar.

8 Lok Seva Sangam, Sion-Chembur Highway, Bombay 400 022-Dr Grugni and Dr N Nadkarni.

9 Poona Dist. Leprosy Committee, Pune 411 001, Maharashtra State-Dr D G Joglekar.

10 GREMALTES, Shenoynagar, Madras 600 030. Tamilnadu State-Dr M Mathews and Dr S Thirunavukarasu.

11 Leprosy Relief Rural Centre, Chettipatty 636 455, Salem District Tamilnadu StateDr N Devarajan.

12 The Sacred Heart Hospital, Kumbakonam 612 401, Thanjavur District, Tamilnadu State-Dr S Thomson.

13 Sagayamatha Hospital \& Leprosy Centre, Pulambady 621 711, Tiruchy District, Tamilnadu State-Dr S M Kabiruddin.

14 St Joseph's Leprosy Hospital, Tuticorin 628 002, Tamilnadu State-Dr T S Petro.

15 St Thomas Hospital \& Leprosy Centre, Chettupattu 606 801, T. S. District Tamilnadu State-Dr J Jayakumar. 